\title{
Jak tworzono „książkę socjalistyczną”? Narady wydawców i księgarzy państw bloku wschodniego 1965-1988
}

Jak już miałem okazję pisać wcześniej ${ }^{1}$ temat instrumentów wpływu Moskwy na kształt polityki wydawniczej w państwach podległych jej wpływom po 1944 r. w zasadzie nie pojawia się jako samodzielny problem badawczy. Co prawda wiemy o udziale urzędników sowieckiej cenzury w tworzeniu jej zrębów w Polsce oraz o tym, że system organizacyjny produkcji i dystrybucji książek był mniej lub bardziej wiernym odwzorowaniem rozwiązań obowiązujących u wschodniego sąsiada, ale gdy przychodzi do skonkretyzowania tych ogólnych opinii nasza wiedza jest ograniczona. Wynika to przede wszystkim $\mathrm{z}$ trudności $\mathrm{w}$ dostępie do dokumentów postsowieckich ${ }^{2}$, ale $z$ drugiej strony jest efektem naszych własnych zaniedbań badawczych.

Tymczasem kwerenda przechowywanych w Archiwum Akt Nowych (AAN) dokumentów z zespołu Komitetu Centralnego Polskiej Zjednoczonej Partii Robotniczej (KC PZPR), a ściślej - głównie z jego Wydziału Kultury, uzupełniona o nieliczne dokumenty odnalezione $\mathrm{w}$ archiwach rosyjskich i o lekturę branżowej prasy fachowej pozwala na przynajmniej częściowe wypełnienie tej białej plamy. W obu typach źródeł zachowało się nieco informacji o organizowanych z inicjatywy sowieckiej naradach przedstawicieli ruchu wydawniczego (rzadziej księgarskiego) państw bloku wschodniego. Są to przede wszystkim sprawozdania $\mathrm{z}$ udziału $\mathrm{w}$ tych posiedzeniach polskich delegacji wraz $\mathrm{z}$ uchwalonymi dokumentami. Czasami można odnaleźć wzmianki o innych, wcześniej odbytych naradach, których dokumentacja się nie zachowała. Przekazy źródłowe o pierwszym takim spotkaniu pochodzą z 1965 r. a o ostatnim - z 1988 r. Nie wiadomo, czy odbywały się one co roku. Wiemy natomiast, że uruchamiały one mechanizm organizowania podobnych spotkań na niższym szczeblu - często po kilka rocznie. Zebrane materiały źródłowe dotyczą posiedzeń odbytych w ciągu

1 D. Jarosz, Władza a książka społeczno-polityczna w PRL 1956-1989, „Z Badań nad Książką i Księgozbiorami Historycznymi” 2013-2014, t. 7-8, s. 133-172.

2 Pisałem o tym szerzej w: Sprawy książki polskiej i jej autorów w sowieckich dokumentach partyjnych z lat 1954-1971, „Z Badań nad Książką i Księgozbiorami Historycznymi” 2015, t. 9, s. 273-284. 
20 lat. Wydaje się, że choć są dalece niekompletne, to wystarczają do dokonania ogólnej charakterystyki tych narad.

\section{Tematyka, „zalecenia”, struktury}

Wiadomości o najwcześniejszej chronologicznie naradzie wydawców z krajów socjalistycznych ${ }^{3}$ dotyczą roku 1965 . W artykule opublikowanym na łamach „Przeglądu Księgarskiego i Wydawniczego” w 1967 r. Leon Marszałek informował o pierwszym seminarium redaktorów encyklopedii w państwach bloku wschodniego, które odbyło się w Warszawie w dniach 14-20 listopada 1966 r. Zostało zorganizowane zgodnie z zaleceniami moskiewskiej narady wydawców encyklopedii „naszego obozu” z października 1965 r. Wówczas to na wniosek strony polskiej postanowiono zwoływać co roku seminaria, których przedmiotem byłyby problemy metodologiczne i edytorskie, związane z przygotowaniem encyklopedii. Mieli w nich uczestniczyć redaktorzy, podczas gdy w naradach wydawców, odbywających się co trzy lata - dyrektorzy i redaktorzy naczelni zainteresowanych wydawnictw. Zorganizowanie pierwszego seminarium powierzono wydawcom polskim. Uczestniczyło w nim 20 redaktorów z siedmiu krajów (Bułgarii, Czechosłowacji, Polski, NRD, Jugosławii, Węgier i ZSRR) ${ }^{4}$.

Cytowana informacja prasowa wskazuje na dwie charakterystyczne cechy tych spotkań. Po pierwsze skupiały one gremia przedstawicieli państw bloku zajmujących się różnymi problemami wydawniczymi. Po drugie, oprócz narad organizowane były różnorodne seminaria o tematyce specjalistycznej.

W hierarchii tych zgromadzeń najważniejsze znaczenie miały narady $\mathrm{z}$ udziałem kierownictw ruchu wydawniczego z krajów bloku wschodniego. Najwcześniejsze chronologicznie odnalezione wzmianki o spotkaniu tej rangi dotyczą roku 1967, kiedy odbyło się ono w Moskwie , a najpóźniejsze

W artykule używam tej nazwy stosowanej w dokumentach z okresu poddanego analizie przy świadomości jej umowności.

4 L. Marszałek, Encyklopedie na warsztacie. Spotkanie encyklopedystów krajów socjalistycznych, „Przegląd Księgarski i Wydawniczy” (dalej: „PKiW”) 1967, nr 2, s. 1-2. Według informacji zawartych w tymże artykule w trakcie warszawskiego seminarium przemawiali m.in. Karol Kuryluk, dyrektor Państwowego Wydawnictwa Naukowego i dyrektor Departamentu Wydawnictw Ministerstwa Kultury i Sztuki Helena Zatorska. W trakcie seminarium referaty wygłosili: red. Lucyna Majzner (Zagadnienie historycznego ujmowania haseł niehistorycznych w encyklopediach uniwersalnych), red. Jan Wojnowski (Cele i metody krzyżowego sprawdzania informacji w pracy redakcji nad encyklopedią) i Bogdan Suchodolski przewodniczący Komitetu Redakcyjnego Wielkiej Encyklopedii Powszechnej PWN (Rola informacyjna i kształcąca encyklopedii).

5 Wzmianka na ten temat - zob. Archiwum Akt Nowych (AAN), Komitet Centralny Polskiej Zjednoczonej Partii Robotniczej (dalej: KC PZPR), Wydział Kultury, LVI-954, Zalecenia narady przedstawicieli państwowych i społecznych kierownictw ruchu wydawniczego krajów socjalistycznych - Berlin 11 grudnia 1969, k. nlb. 
- narady warszawskiej (28 listopada - 3 grudnia 1988 r.) ${ }^{6}$. To tam zapadały najważniejsze decyzje (mające zwykle formę podpisywanych przez uczestników „,zaleceń”, zobowiązujące wszystkich sygnatariuszy do realizacji ustalonych przedsięwzięć wydawniczych.

Te ogólne ustalenia były uściślane i dostosowywane do praktyki pracy różnych typów wydawnictw w trakcie spotkań ich przedstawicieli. Osobne zgromadzenia organizowali więc m.in. (jak już wcześniej zasygnalizowano) wydawcy encyklopedii, literatury naukowo-technicznej (piętnaście spotkań do 1987 r. $)^{7}$, słownikowej ${ }^{8}$, popularnonaukowej ${ }^{9}$, ekonomicznej ${ }^{10}$, wydawnictwa artystyczne ${ }^{11}$, księgarze ${ }^{12}$.

Wiadomości na temat przebiegu omawianych zgromadzeń pochodzą z analizy wskazanych już wcześniej dokumentów archiwalnych. Artykuły prasowe, publikowane w „Przeglądzie Księgarskim i Wydawniczym”, mają dużo bardziej ograniczoną wartość poznawczą ze względu na ich schematyzm.

Charakterystykę spotkań należy rozpocząć od wzmiankowanych narad kierownictw ruchu wydawniczego państw bloku. Co ważne, odbywały się one zwykle przy udziale przedstawicieli wydawnictw społeczno-politycznych, co wskazywało na wysoką rangę tej literatury w koncepcjach inicjatorów zgromadzeń.

Jak już wzmiankowano, takie posiedzenie przedstawicieli organów wydawniczych państw bloku wschodniego odbyło się w 1967 r. w Moskwie, a dwa wcześniejsze - w Budapeszcie i Sofii ${ }^{13}$. Dość nerwowy przebieg miała kolejna narada w Smolenicach na Słowacji, odbywająca się w dniach 22-24 kwietnia 1968 r., w atmosferze napięcia poprzedzającego zbrojną interwencję wojsk pięciu państw - stron Układu Warszawskiego w Czechosłowacji. Wzięli w niej udział delegaci z Bułgarii, Węgier, NRD, Mongolii, Rumunii, ZSRR, Czechosłowacji, Jugosławii i Polski. Omówiono m.in. kwestię wydań książek w związku ze 150 rocznicą urodzin Marksa, stuleciem urodzin Lenina i 25-leciem pokonania faszyzmu w Europie. Przedstawiciel Czechosłowacji najpierw nie chciał przyjechać, a gdy jednak zdecydował się

\footnotetext{
${ }^{6}$ AAN, KC PZPR, Wydział Kultury, LVI-322, Projekt zaleceń narady przedstawicieli kierownictw ruchu wydawniczego krajów socjalistycznych w Warszawie (28 listopada - 3 grudnia 1988), k. nlb.

Zob. jak wyżej.

Międzynarodowe spotkanie leksykografów, „PKiW” 1974, nr 19-20, s. 5, 11.

9 Z. Nosek, Dalszy krok we wspótpracy wydawnictw krajów socjalistycznych, „PKiW” 1969, nr 10, s. $5,11$.

${ }_{10}$ IV Konferencja Wydawnictw Literatury Ekonomicznej Krajów Socjalistycznych, „PKiW” 1978 , nr 2, s. 5, 8 .

11 E. Muszyńska, E. Piliszek, Ksiązka o sztuce w rozwiniętym społeczeństwie socjalistycznym, „PKiW” 1979, nr 1, s. 3, 10-11.

12 T. Hussak, Narada w Bratysławie, „PKiW” 1984, nr 1, s. 1, 8.

13 AAN, KC PZPR, Wydział Kultury, LVI-954.
} 
na udział - wyraził sceptycyzm co do możliwości przyjęcia wspólnego dokumentu, a po jego sformułowaniu - nie podpisał ustalonych rekomendacji ${ }^{14}$.

Kolejne spotkanie o analogicznym charakterze miało miejsce we wschodnim Berlinie w dniach 9-13 grudnia $1969 \mathrm{r}$. W przyjętych zaleceniach stwierdzano, że omówiono stan przygotowań do planowanej na kwiecień-maj 1970 r. Międzynarodowej Wystawy Książki w Moskwie, poświęconej stuleciu urodzin Lenina oraz do Międzynarodowej Wystawy Sztuki Edytorskiej w Lipsku w 1971 r. Pisano również, że literatura wydawana w latach poprzedzających naradę przez uczestniczące w niej kraje socjalistyczne była „pomocna w walce przeciwko imperialistycznej ideologicznej dywersji i kontrrewolucji”, upowszechniała „nowoczesną wiedzę i jej naukowe zdobycze", stanowiła aktywną pomoc w budowie socjalizmu. Zalecano zwrócenie „baczniejszej uwagi na problem światopoglądowego wzbogacenia literatury na gruncie marksizmu-leninizmu, dla zapobieżenia ew. odideologizowaniu wydawanej literatury"15. Dyskutowano również nad pomysłem utworzenia w ramach Rady Wzajemnej Pomocy Gospodarczej (RWPG) grupy roboczej (sekcji) dla koordynacji współpracy wydawniczej. Zalecano dokonanie wymiany planów wydawniczych z zakresu literatury w związku ze 150 rocznicą urodzin Fryderyka Engelsa ${ }^{16}$.

Współpraca przy wydawnictwach rocznicowych była również tematem rozważań na kolejnej naradzie kierownictw ruchu wydawniczego krajów socjalistycznych w Pradze (1-5 listopada 1971 r.). Przyjęto wówczas porozumienie o systematycznej koordynacji i uzgodnieniu działalności w związku z uczestnictwem w wystawach międzynarodowych, targach książki, sympozjach, szczególnie tych przewidzianych w programie Międzynarodowego Roku Książki (1972). Dokumentu nie podpisała delegacja rumuńska, coraz bardziej dystansująca się od polityki Kremla ${ }^{17}$.

W zaleceniach narady hawańskiej, która obradowała w dniach 27-30 stycznia 1976 r. (z udziałem przedstawicieli Bułgarii, CSRS, Republiki Kuby, NRD, Polski, Rumunii, Węgier, Demokratycznej Republiki Wietnamu i ZSRR) wskazywano na konieczność kontynuacji prac nad wspólnymi pozycjami wydawniczymi o tematyce społeczno-politycznej skiero-

14 Rosijskij Gosudartwiennyj Archiw Nowiejszej Isstorii (dalej: RGANI), f. 5, op. 60, jed. chr. 31, rolik 969600, Notatka Michajłowa, przewodniczącego Komitetu ds. Druku przy Radzie Najwyższej ZSRR, kwiecień 1968.

15 AAN, KCPZPR, Wydział Kultury, LVI-954, op. cit.

16 Zob. jak wyżej.

17 RGANI, f. 5, op. 63, d. 97, Stykalin, przewodniczący Komitetu do spraw Druku przy Radzie Ministrów ZSRR, 13 XI 1971, k. nlb. Delegacja rumuńska ogłosiła votum separatum wobec zaleceń narady kierownictw ruchu wydawniczego krajów socjalistycznych w Berlinie (9-13 grudnia 1969). Zob. AAN, Wydział Kultury, LVI-954, L. Karnkowski, Sprawozdanie z przebiegu narady kierownictw ruchu wydawniczego krajów socjalistycznych w Berlinie w dniach 9-13 XII 1969, k. nlb. 
wanymi przede wszystkim przeciwko imperializmowi, kolonializmowi, neokolonializmowi, faszyzmowi, dyskryminacji rasowej oraz nad pozycjami poświęconymi walce z ,ideologią burżuazyjną" i „rewizjonizmem”. Poparto ideę dalszego wydawania dotychczasowych i zainicjowania nowych wspólnych serii wydawniczych (o czym - w dalszej części tego studium). Postanowiono zwrócić szczególną uwagę na przygotowanie pozycji poświęconych 60-leciu „Wielkiej Rewolucji Październikowej”, rocznicom ,powstania władzy ludowej krajów socjalistycznych”. W zaleceniach narady zapisano plany zorganizowania w latach 1976-1977 kolejnych spotkań specjalistycznych o różnym charakterze, w tym m.in. wydawców literatury turystycznej, uczestniczących w międzynarodowej serii „Ochrona Przyrody”, literatury prawniczej, ekonomicznej, weterynaryjnej, medycznej, technicznej, z zakresu komunikacji, wydawnictw poświęconych olimpiadzie 1980 r. i uczestników projektów publikowania wspólnych serii wydawniczych ${ }^{18}$.

$\mathrm{Na}$ przełomie lat 70. i 80. pojawił się nowy kierunek koordynowanej aktywności wydawniczej, zainicjowany przez kierownictwa partyjne państw bloku. Zgodnie z zaleceniami, opracowanymi przez naradę sekretarzy do spraw stosunków międzynarodowych i pracy ideologicznej Komitetów Centralnych partii komunistycznych i robotniczych państw bloku oraz decyzji, przyjętych na zjazdach tychże partii, przedstawiciele organów kierowniczych ruchu wydawniczego tych krajów na naradzie zwołanej do Budapesztu w grudniu 1980 r. postanowili powołać specjalną Radę dla koordynacji wydawania „książki socjalistycznej” i jej rozpowszechniania w krajach niesocjalistycznych. Ustalono również preferowaną tematykę tych publikacji. Miały to być tłumaczenia podstawowych dzieł klasyków marksizmu-leninizmu, prace służące ,umocnieniu światopoglądu socjalistycznego", traktujące o marksizmie-leninizmie, w tym zwłaszcza takie, które „odgrywają wielką rolę w tworzeniu i umacnianiu rewolucyjnych partii klasy robotniczej” oraz omawiające „doświadczenia różnych etapów społecznych przeobrażeń w rozwiniętych krajach socjalistycznych"19.

Nowa struktura organizacyjna nazwana ostatecznie Radą Koordynacyjną Krajów Socjalistycznych dla Wydawnictw Literatury Społecznej, Socjalistycznej i jej Rozpowszechniania w Krajach Niesocjalistycznych (dalej nazywaną Radą Koordynacyjną) ukonstytuowała się na naradzie

18 AAN, KC PZPR, Wydział Kultury, LVI-321, Zalecenia hawańskiej narady przedstawicieli kierownictw ruchu wydawniczego krajów socjalistycznych, Hawana 30 stycznia 1976, k. nlb.

19 AAN, KC PZPR, Wydział Kultury, LVI-987, Tezy I posiedzenia inauguracyjnego Rady Koordynacyjnej krajów socjalistycznych do spraw wydawania literatury socjalistycznej i jej rozpowszechniania w krajach niesocjalistycznych, Berlin 28 sierpnia 1981, k. nlb. 
kierownictw ruchu wydawniczego w Berlinie, która odbyła się w dniach 26-28 sierpnia 1981 r. Uznano wówczas za celowe utworzenie czasowej grupy roboczej dla przygotowania literatury krajów socjalistycznych dla niesocjalistycznych krajów Azji Południowo-Wschodniej ${ }^{20}$.

Ten kierunek działań kontynuowano na posiedzeniu moskiewskim w listopadzie 1981 r. Uczestnicy spotkania oprócz uzgodnienia politycznej deklaracji, wyrażającej oburzenie „antykubańską kampanią USA i kampanią w sprawie tzw. międzynarodowego terroryzmu i absurdalnymi obciążeniem odpowiedzialnością za to ZSRR i innych K[rajów] S[ocjalistycznych]" postanowili podjąć kroki w celu rozszerzenia edycji książek o socjalistycznym państwie i prawie w językach: angielskim, francuskim, hiszpańskim, niemieckim, a w szczególności starannie realizować tematykę zaaprobowaną przez przedstawicieli narady stowarzyszeń prawników z „bratnich krajów”, odbytej w Warszawie 6 października $1981 \mathrm{r}^{21}$

Mocno akcentowana ideologiczna retoryka uchwalanych dokumentów łączyła się z dążeniem do tego, aby mechanizm posiedzeń obejmował coraz większą liczbę państw uzależnionych od Kremla. Stąd uczestnikami narad byli nie tylko przedstawiciele wydawców z Europy Środkowo-Wschodniej, ale także z niektórych państw pozaeuropejskich. Dobrym przykładem na potwierdzenie tej tezy jest chociażby spotkanie sofijskie, mające miejsce w dniach 15-18 listopada 1982 r. Obok przedstawicieli Bułgarii, Czechosłowacji, Polski, NRD i ZSRR, pojawili się tam delegaci z Ludowej Republiki Angoli, Socjalistycznej Etiopii, Republiki Kuby, Mongolii, Socjalistycznej Republiki Wietnamu i - po raz pierwszy - z Laotańskiej Republiki Ludowo-Demokratycznej, Kampuczańskiej Republiki Ludowej i Nikaragui. Jak zapisano w przyjętych zaleceniach wysoko oceniono aktywizację pracy organów kierowniczych ruchu wydawniczego krajów socjalistycznych „W zakresie wydawania literatury demaskującej reakcyjną istotę imperializmu, antykomunizmu, antyradzieckości, politykę wzniecania psychozy militarystycznej". W zaleceniach dowartościowano prace w zakresie wydawania i rozpowszechniania literatury poświęconej ważnym datom w historii ruchu robotniczego i krajów socjalistycznych: 65 rocznicy „Wielkiej Socjalistycznej Rewolucji Październikowej”, 100-leciu urodzin Georgi Dymitrowa ${ }^{22}$,

20 AAN, KC PZPR, Wydział Kultury, LVI-987, Protokół z 1. posiedzenia (konstytuującej się) Rady Koordynacyjnej Krajów Socjalistycznych dla Wydawnictw Literatury Społecznej, Socjalistycznej i jej rozpowszechniania w krajach niesocjalistycznych, k. nlb.

${ }^{21}$ AAN, KC PZPR, Wydział Kultury, LVI-986, Zalecenia Narady przedstawicieli wydawnictw literatury społeczno-politycznej oraz kierowników ruchu wydawniczego krajów socjalistycznych, Moskwa 23-28 listopada 1981, k. nlb.

22 Georgi Dymitrow (1882-1949) - bułgarski komunista, w latach 1934-1943 sekretarz generalny Międzynarodówki Komunistycznej, premier Bułgarii w latach 1946-1949. 
60-leciu urodzin dr. Antónia Agostinha $\mathrm{Neto}^{23}$. Za przedsięwzięcie o wielkim znaczeniu uznano przygotowanie i wydanie książek na 100-lecie polskiego ruchu robotniczego, 165 rocznicę urodzin Karola Marksa i 100-lecie jego śmierci, 115 rocznicę urodzin Włodzimierza Lenina, 40-lecie zwycięstwa nad faszyzmem i powstania wielu państw socjalistycznych, 60-lecie proklamowania Mongolskiej Republiki Ludowej (w 1924 r.), 25-lecie zwycięstwa rewolucji kubańskiej, 35-lecie RWPG i 30-lecie Paktu Warszawskiego.

W Sofii, zgodnie z obowiązującą rutyną, oceniono przebieg realizacji niektórych wspólnych przedsięwzięć wydawniczych oraz projektowano nowe. Zaplanowano kolejne spotkania wydawców poszczególnych typów literatury do roku 1984 włącznie. Znalazły się wśród nich m.in. narady z udziałem przedstawicieli wydawnictw publikujących literaturę z zakresu ochrony środowiska naturalnego, sportową, naukowo-techniczną, dziecięcą i młodzieżową.

Tematy przewodnie nowych publikacji zostały określone w języku komunistycznej nowomowy i nie odbiegały od wcześniej obowiązującego schematu. Były to: „osiągnięcia realnego socjalizmu w dziedzinie budownictwa socjalno-ekonomicznego i kulturalnego”, „wysoka efektywność braterskiej współpracy między państwami socjalistycznymi, integracji ekonomicznej realizowanej w ramach RWPG", rola Paktu Warszawskiego w zachowaniu pokoju, pokojowa polityka zagraniczna ZSRR i innych krajów socjalistycznych, „tryumf leninowskiej polityki narodowościowej” w tych krajach, walka o pokój i bezpieczeństwo narodów, „historyczna przewaga socjalizmu w zakresie zapewnienia autentycznych praw i swobód człowieka”, doświadczenia i zwiększenie efektywności pracy ideologicznej „bratnich partii”, współczesny światowy proces rewolucyjny i międzynarodowy ruch robotniczy i komunistyczny, ,antyhumanitarna istota współczesnego imperializmu oraz burżuazyjnego sposobu życia”, „imperialistyczna polityka USA”, „międzynarodowy syjonizm - orężem imperialistycznej agresji i ekspansji”, „neokolonialna polityka państw imperialistycznych”24.

Odnalezione sprawozdania z kolejnych posiedzeń przedstawicieli wydawnictw literatury społeczno-politycznej oraz kierowników ruchu wydawniczego krajów socjalistycznych w Moskwie (6-11 grudnia 1982 r., 5-10 grudnia 1983 r.) oraz w Warszawie (4-7 grudnia 1984 r.) świadczą, że sposób traktowania książki jako oręża walki ideologicznej nie zmienił się.

W zaleceniach narady moskiewskiej z grudnia 1982 r. czytamy, że zdaniem jej uczestników ,gwałtowne zaostrzenie walki ideologicznej na obec-

23 António Agostinho Neto (1922-1979) - angolski lewicowy polityk i poeta, w latach 1975-1979 pierwszy prezydent niepodległej Angoli.

24 AAN, KC PZPR, Wydział Kultury, LVI-987, Zalecenia sofijskiej narady przedstawicieli kierowniczych organów ruchu wydawniczego krajów socjalistycznych [1982], k. nlb. 
nym etapie, prowadzenie przez koła imperialistyczne USA i ich sojuszników «wojny psychologicznej» przeciwko krajom socjalistycznym, wykorzystywanie $\mathrm{w}$ tej wojnie $\mathrm{w}$ szerokim zakresie $\mathrm{z}$ góry obmyślonego kłamstwa i złośliwej dezinformacji z powodu wewnętrznej i zagranicznej polityki krajów wspólnoty socjalistycznej, partii komunistycznych i robotniczych, jawne ogłoszenie przez prezydenta USA nowej «wyprawy krzyżowej» przeciwko komunizmowi - wszystko to wymaga od wydawców realizacji dodatkowych poczynań w zakresie wydawania literatury, aktywnie przeciwdziałającej destrukcyjnym akcjom propagandowym administracji waszyngtońskiej i krajów NATO”25.

Na kolejnym spotkaniu moskiewskim w grudniu 1983 r. szczególnie mocno zaakcentowano konieczność wprowadzenia większej liczby publikacji o charakterze ateistycznym. Zalecano, aby w wydaniach poświęconych marksistowsko-leninowskiemu religioznawstwu pokazać, że komuniści „,zawsze potępiali każde formy przemocy w zwalczaniu religii, wychodząc z założenia, że fałszywe poglądy i wyobrażenia obumierają w miarę umacniania się socjalizmu, kształtowania się naukowego światopoglądu, w warunkach ukierunkowanej pracy wśród mas". Jednocześnie komuniści występowali ,zdecydowanie przeciwko wykorzystywaniu religii w celach antykomunistycznych do walki z socjalizmem i ruchem wyzwoleńczym narodów". Narada przedyskutowała i zatwierdziła wykaz pozycji o tej tematyce, które miały zostać rozpatrzone jako przedmiot ewentualnego przekładu i wydania w innych krajach. Poza tym ,uczestnicy narady uzgodnili przygotowanie wspólnymi siłami oraz wydanie pracy pod takim np. tytułem: «Wykorzystanie przez reakcję czynnika religijnego w walce przeciwko socjalizmowi»»" ${ }^{26}$.

$\mathrm{Na}$ posiedzeniu warszawskim w grudniu 1984 r. w ramach kontynuacji tego wątku dyskutowano nad ,rolą literatury filozoficzno-światopoglądowej w ideowym wychowaniu młodych pokoleń”. Mówiono o roli literatury „filozoficzno-światopoglądowej" w kształtowaniu naukowego, laickiego poglądu na świat, na jej zadanie „upowszechniania etycznych wartości marksizmu”. Zwrócono uwagę, że w walce ideologicznej literatura ta jest jednym $\mathrm{z}$ bardzo ważnych elementów zdobywania bazy społecznej w walce politycznej z racji „pełnienia przez nią roli propagandowej i agitacyjnej”"27.

25 AAN, KC PZPR, LVI-986, Zalecenia narady przedstawicieli wydawnictw literatury społeczno-politycznej i organów wydawniczych krajów socjalistycznych, Moskwa, 6-11 grudnia 1982 r., k. nlb.

26 AAN, KC PZPR, Wydział Kultury, LVI-1479, Zalecenia narady przedstawicieli wydawnictw literatury społeczno-politycznej i kierowniczych organów wydawniczych krajów socjalistycznych, Moskwa 5-10 grudnia 1983, k. nlb.

27 AAN, KC PZPR Wydział Kultury, LVI-312, Zalecenia narady wydawców literatury społeczno-politycznej i przedstawicieli kierowniczych organów wydawniczych krajów socjalistycznych, Warszawa 4-7 grudnia 1984, k. nlb. 
Jak wcześniej wzmiankowano, ostatnia narada kierownictw ruchu wydawniczego krajów socjalistycznych, której zalecenia zachowały się w analizowanym zbiorze dokumentów odbyła się w Warszawie w dniach 28 listopada - 3 grudnia $1988 \mathrm{r}$. W posiedzeniu uczestniczyli przedstawiciele Bułgarii, Czechosłowacji, Korei Północnej, Mongolii, NRD, Polski, Węgier i ZSRR, a w charakterze obserwatorów wzięli udział reprezentanci Laotańskiej Republiki Ludowo-Demokratycznej, Socjalistycznej Republiki Wietnamu i RWPG.

$\mathrm{Na}$ zaleceniach narady, sformułowanych w wyraźnie mniej zideologizowanym języku, wyraźne piętno wywarły przemiany społeczno-ekonomiczne i polityczne, jakie zaczęły się dokonywać w bloku wschodnim i które ,w uchwałach zjazdów i konferencji bratnich partii nazywane są odnową, przebudową lub dalszym doskonaleniem rozwiniętego społeczeństwa socjalistycznego". „W każdym przypadku chodzi o proces głębokich przemian we wszystkich sferach życia społecznego". Wynikały z tego poważne zadania dla ruchu wydawniczego. Tym razem jako priorytet traktowano publikowanie rezultatów poszukiwań naukowych i popularyzowanie postępu naukowo-technicznego. Szczególna uwaga miała być zwrócona na wydawanie literatury popularno-naukowej dla młodzieży. Zwracano ponadto uwagę, że „Wkraczamy w okres komputeryzacji procesu wydawniczego. Daje to możliwości współpracy służącej przyspieszeniu procesu wydawania książek". Podstawową formą kooperacji miała stać się wymiana programów, stworzenie wspólnego banku informacji wydawniczych. Jedno z głównych zadań wydawców widziano w skróceniu cyklu produkcyjnego książki ze szczególnym uwzględnieniem książki społeczno-politycznej i naukowo-technicznej. W tym celu deklarowano poparcie dla bezpośrednich kontaktów między wydawnictwami oraz kooperacji, tak aby szybciej przygotowywać i wydawać przekłady w powiązaniu z głównymi kierunkami Kompleksowego Programu Postępu Naukowo-Technicznego krajów członkowskich RWPG. Zgodnie z tym programem wydawcy mieli zwrócić uwagę przede wszystkim na publikację książek podejmujących tematykę: elektronizacji gospodarki narodowej, kompleksowej automatyzacji, energetyki jądrowej, nowych materiałów oraz technologii ich produkcji i obróbki, biotechnologii i ochrony naturalnego środowiska człowieka. Konstatowano, że współpraca między kierownictwami ruchu wydawniczego i wydawnictwami krajów uczestniczących w dwu i wielostronnej kooperacji została znacznie rozszerzona, a jej formy stały się bardziej zróżnicowane, czego dobrym przykładem było powołanie polsko-radzieckiej spółki poligraficzno-wydawniczej „Orbita”. Członkowie narady uznali za pożądane doskonalenie współpracy w zakresie wydawania literatury pięknej w językach obcych. Stwierdzono, że należy popierać współpracę wydawnictw zainteresowanych wspólną ekspansją na rynki krajów trzecich jako konkretną formę promocji książki socjalistycznej za granicą. Zalecono likwidację Rady Kon- 
sultacyjnej - uznano ją za niecelową ze względu na „zróżnicowanie możliwości poszczególnych" członków ${ }^{28}$.

Jak już stwierdzono wcześniej idee i koncepcje, które wypracowywały narady przedstawicieli kierownictw ruchu wydawniczego państw bloku wschodniego były „rozpisywane” na zalecenia, formułowane na konferencjach dla przedstawicieli poszczególnych typów wydawnictw i ruchu księgarskiego. Informacje na ten temat w poddanej kwerendzie bazie źródłowej są dość lakoniczne.

O konferencjach księgarzy wzmiankował „Przegląd Księgarski i Wydawniczy”. Najczęściej pisał o nich Tadeusz Hussak, w latach 1962-1993 przewodniczący Zarządu Głównego Stowarzyszenia Księgarzy Polskich i uczestnik tych spotkań. Z (najczęściej krótkich i schematycznych) notatek $^{29}$ sprawozdawczych wynika, że księgarze krajów socjalistycznych po raz pierwszy zebrali się w maju 1973 r. w Moskwie ${ }^{30}$. Na trzecim tego typu spotkaniu (6-10 czerwca 1977 r. w Warszawie) goście z ZSRR przedstawili referat pt. „Ideologiczne kierunki i formy organizacyjne oraz efektywność propagandy książki”. Najważniejszy referat polski, wygłoszony przez Kazimierza Majerowicza, dyrektora Naczelnego Zjednoczenia Księgarstwa w Warszawie nosił tytuł: „Doświadczenia księgarstwa polskiego w zakresie rozbudowy sieci księgarskiej oraz przygotowania zawodowego kadr (ze szczególnym uwzględnieniem rozwoju sieci w zakładach przemysłowych i na wsi)". Za zadanie szczególnie istotne w ,aktualnej sytuacji międzynarodowej" uznano upowszechnianie i popularyzację książek społeczno-politycznych, opracowanych dla różnego rodzaju odbiorców według ich poziomów czytelniczych. Polskimi doświadczeniami w tym zakresie podzielił się T. Hussak, który mówił o dorocznych Dniach Książki Społeczno-Politycznej „Człowiek - Świat - Polityka" ${ }^{1}$. Na wspólnych spotkaniach zastanawiano się również nad elektronicznym przetwarzaniem danych w księgarstwie, sposobami badania rynku księgarskiego itp. ${ }^{32}$

Komunikaty i sprawozdania z konferencji i narad wydawców różnego typu literatury były formułowane w języku propagandowej nowomowy, dostosowanej z jednej strony do stylistyki zaleceń narad kierownictw ruchu

28 AAN, KC PZPR, Wydział Kultury, LVI-1537, Zalecenia narady przedstawicieli kierownictw ruchu wydawniczego krajów socjalistycznych w Warszawie, k. nlb.

29 Zob. m.in.: T. H., Międzynarodowa Konferencja Księgarzy Krajów Socjalistycznych, „PKiW” 1979, nr 12, s. 1, 11; T. H., Spotkanie w Budapeszcie, „PKiW” 1981, nr 11-12, s. 9; T. Hussak, Narada w Bratystawie, „PKiW” 1984, nr 1, s. 1, 8.

30 T. Hussak, II Międzynarodowa Konferencja Księgarstwa Krajów Socjalistycznych, „PKiW” 1975, nr 13-14, s. 1, 3.

31 Zalecenia III Międzynarodowej Konferencji Księgarzy Krajów Socjalistycznych, „PKiW” 1977, nr 15-16, s. 1, 7, 9 .

32 T. Hussak, II Międzynarodowa... 
wydawniczego, z drugiej - do specyfiki wydawniczej. Oto dwa (z wielu) przykładów efektów tego melanżu. Na obradującej w listopadzie $1978 \mathrm{r}$. w Warszawie V Międzynarodowej Konferencji Wydawnictw Artystycznych Krajów Socjalistycznych (pierwsza odbyła się 15 lat wcześniej w Berlinie), zorganizowanej przez Wydawnictwo Arkady, jego redaktor naczelny Eugeniusz Piliszek mówił, że „«socjalistyczna książka artystyczna» kształtuje twórcze, zaangażowane postawy obywateli, umożliwiając im przyswojenie wartości najlepszych, postępowych dzieł sztuki dawnej i współczesnej, sprzyja kształtowaniu postaw internacjonalistycznych poprzez zapoznawanie społeczeństwa ze sztuką innych narodów, wychowuje w duchu patriotyzmu i poszanowania dorobku minionych pokoleń przez zapoznawanie z rodzimym dorobkiem artystycznym”. Podkreślał rolę książki o sztuce w walce z „koncepcjami antyhumanistycznymi, wrogimi socjalizmowi" ${ }^{33}$.

Tadeusz Kosmala w referacie wygłoszonym na Międzynarodowej Konferencji Wydawnictw Literatury Popularnonaukowej w Jabłonnie (31 października - 5 listopada 1977 r.) twierdzit, że literatura popularno-naukowa winna aktywnie uczestniczyć w kształtowaniu światopoglądu i postaw obywatelskich i w walce $\mathrm{z}$ obcą ideologią, ma też obowiązek aktywnego popularyzowania marksizmu-leninizmu, ofensywnego demaskowania obcych wpływów ideologicznych. Przed wydawnictwami tego typu stoją zadania mobilizowania do realizacji podnoszenia potencjału kraju, przysposabiania do szerokiego udziału w życiu społecznym i politycznym, wspomagania przygotowania do zawodu ${ }^{34}$.

\section{Efekty}

Z pewnością formułowanie zaleceń $\mathrm{z}$ narad i konferencji wydawców i księgarzy państw bloku wschodniego stanowiło element odgórnie narzuconego rytuału. Wyłamanie się z niego było trudne i uzależnione od ,wielkiej polityki", o której celach i strategii decydowano na najwyższych szczeblach władzy. Jak już wzmiankowano wcześniej, z zachowanych akt wynika, że odrębne stanowisko próbowali zająć przedstawiciele czechosłowackiego ruchu wydawniczego w okresie przed interwencją państw bloku wschodniego w 1968 r. oraz rumuńskiego, którzy od 1969 r. dystansowali się wobec wielu zaleceń narad, nie we wszystkich uczestniczyli, ale nie zerwali kontaktów z wydawcami z bloku wschodniego. Czy jednak owe rytualne wytyczne skutkowały jakimiś rzeczywistymi działaniami, przekładały się na konkretne

33 E. Muszyńska, E. Piliszek, Książka o sztuce w rozwiniętym społeczeństwie socjalistycznym, „PKiW” 1979, nr 1, s. 3, 10-11.

34 T. Kosmala, Książka popularnonaukowa $w$ rozwiniętym społeczeństwie socjalistycznym, „PKiW” 1978, nr 1, s. 3-5. 
efekty - a jeżeli tak, to na jakie? Wreszcie warto zastanowić się, jaki był polski wkład w te wspólne przedsięwzięcia.

Zarówno zalecenia narad kierownictw ruchu wydawniczego, jak też specjalistycznych konferencji postulowały wydawanie thumaczeń wybranych książek w ramach krajów socjalistycznych na języki narodowe oraz tworzenie wspólnych serii wydawniczych, zawierających wcześniej wytypowane pozycje o podobnej tematyce lub nawet te same, thumaczone na języki środkowoeuropejskie.

Wśród tych serii ważne znaczenie przypisywano „Bibliotece Zwycięstwa”. W jej ramach Spółdzielnia Wydawnicza „Czytelnik” wydała w latach 1975-1982 ponad 30 dzieł literatury pięknej z państw bloku wschodniego, w tym m.in.: Strofy o walce i braterstwie: antologia poezji (wiersze polskie i tłumaczone z bułgarskiego, czeskiego, niemieckiego, rosyjskiego, słowackiego i węgierskiego), Reportaż spod szubienicy Juliusa Fučika, Siódmy krzyż Anny Seghers, W stronę zachodu stońca: opowieści i opowiadania o Wielkiej Wojnie Narodowej (przekład z rosyjskiego).

Na wzmiankowanej już naradzie hawańskiej w styczniu 1976 r. wysunięto inicjatywę uruchomienia nowej serii pn. „Biblioteka Poezji Europejskiej”35, w ramach której miały ukazywać się edycje dwujęzyczne. Jednak realizacja tego przedsięwzięcia napotkała na duże trudności. Informacje zebrane przez stronę polską przed warszawską naradą w $1988 \mathrm{r}$. potwierdzały dużą rezerwę wobec tego pomysłu. Kierownictwo ruchu wydawniczego w NRD podkreślało, że trudno mówić o poezji europejskiej, skoro nawet nie wszystkie kraje socjalistyczne przystąpiły do tych działań, a wydawców spoza bloku wschodniego nie udało się pozyskać. Według wydawców czechosłowackich niskie nakłady wydawanych tomów czyniły to przedsięwzięcie niedochodowym. Edycja tej serii w ZSRR była do tego czasu w zasadzie zakończona. Jedynie strona węgierska wprowadziła do niej tomy krajów niesocjalistycznych, z kręgu niemieckojęzycznego. Polska jeszcze w 1988 r. nie zdecydowała się na realizację tego pomysłu na skutek rozbieżności co do jego kształtu. Chodziło o to, że polscy wydawcy opublikowali już w latach 1977-1987 kolekcje literatur: radzieckiej, bułgarskiej, węgierskiej, NRD i kubańskiej, zawierające również przekłady poezji i w związku z tym nie widzieli potrzeby dublowania tej tematyki ${ }^{36}$.

Nieco większy był udział Polski w innych wspólnych przedsięwzięciach wydawniczych zalecanych przez narady. I tak w ramach serii „Krytyka Burżuazyjnej Ideologii i Rewizjonizmu" od momentu powstania (w 1975 r.) do

35 AAN, KC PZPR, Wydział Kultury LVI-321, Zalecenia hawańskiej narady...

36 AAN, KC PZPR, Wydział Kultury, LVI-1537, Sprawozdanie o wykonaniu zleceń narady kierownictw ruchu wydawniczego krajów socjalistycznych w Berlinie, 1986 przygotowane przez Polskę na naradę w Warszawie, listopad 1988 - grudzień 1988, Warszawa, listopad 1988, k. nlb. 
1987 wydano 15 książek. W latach 1977-1986 w powstałej w 1976 r. serii „Socjalizm: Doświadczenia, Problemy, Perspektywy” (zmienioną potem na: „Realny Socjalizm”) opublikowano (według katalogu Biblioteki Narodowej) dziewięć pozycji ${ }^{37}$. W serii „Maoizm - Zagrożenie dla Świata” wydano w Polsce tylko dwie książki (Andrzeja Halimarskiego Trzy kręgi polityki zagranicznej Chin, Warszawa 1982 oraz S. G. Jurkowa, Azja w planach Pekinu, tł. z rosyjskiego Henryk Widłaszewski, Warszawa 1983) ${ }^{38}$ a w kolekcji książek pod wspólnym tytułem - „Ludzkość u Progu XXI wieku” - jedną pozycję: pracę zbiorową Problemy ludnościowe (pod red. Mikołaja Latucha, Warszawa 1986). Jak widać literatura społeczno-polityczna zajmowała (obok beletrystyki) najważniejsze miejsce w kolekcjach książek wydawanych w ramach współpracy państw bloku wschodniego.

Warto jednak wskazać, że kooperacja nie ograniczała się tylko do publikacji pozycji z tej grupy i przybierała również inne formy. Niektóre z podejmowanych przedsięwzięć obejmowały tylko wybrane państwa. $\mathrm{Z}$ dostępnych dokumentów wiemy na przykład, że na naradzie przedstawicieli wydawnictw encyklopedycznych, która odbyła się w Moskwie w grudniu 1977 r. T. Kosmala, dyrektor i naczelny redaktor Wiedzy Powszechnej informował o publikacji przez kierowaną przez niego oficynę Encyklopedii rewolucji październikowej na podstawie słownika encyklopedycznego opublikowanego w ZSRR, przez wydawnictwo „Sowietskaja Enciklopedia"39. Wymierne efekty przyniosła współpraca w zakresie publikacji artystycznych. Polskie wydawnictwo Arkady kooperowało przede wszystkim ze swym odpowiednikiem w Berlinie wschodnim - Henschelverlag Kunst und Gesellschaft i z węgierską „Corviną” oraz incyden-

${ }^{37}$ Znalazły się wśród nich m.in. następujące tytułu: Ekonomiczne problemy rewolucji naukowo-technicznej w socjalizmie, red. L. M. Gatovskij, i in., tł. z rosyjskiego A. Rosłan, Warszawa 1978; L.P. Jewstigniejewa, Ksztaltowanie potrzeb w rozwiniętym społeczeństwie socjalistycznym, tł. z rosyjskiego J. Skrzypkowa, Warszawa 1979; Płaca w ustroju socjalistycznym : zagadnienia teorii i praktyki, red. nauk. wyd. pol. W. Krencik, tł. z rosyjskiego A. Rosłan, Warszawa 1978; Socjalistyczny internacjonalizm: teoria i praktyka stosunków międzynarodowych nowego typu, red. S. Angiełow, tł. z rosyjskiego T. Bujnowska i in., Warszawa 1982; Socjalizm a dobrobyt spoteczny, tł. z rosyjskiego N. Kuźmicz, Warszawa 1978; Wyższość socjalizmu jako systemu społecznego, red. P. A. Ignatowski, T. M. Jaroszewski, tł. z rosyjskiego: R. Sroczyński, H. Widłaszewski, S. Wieczorek, Warszawa 1980; M. Domagała, Kontrola zgodności prawa z konstytucja w europejskich państwach socjalistycznych, Warszawa 1986; J. Mazur, Planowanie tworzenia prawa w państwie socjalistycznym, Warszawa 1986. Ogółem, we wszystkich krajach wydających tę serię do 1984 r. opublikowano w jej ramach 108 książek. Zob. AAN, KC PZPR, Wydział Kultury, LVI-312, O zwiększeniu roli książki w propagandzie bratniej współpracy krajów socjalistycznych, w walce o pokój, przeciwko reakcji imperialistycznej. Komunikat delegacji radzieckiej na Naradzie Kierownictw Organów Krajów Socjalistycznych, Moskwa 20 listopada 1984, k. nlb.

38 AAN, KC PZPR, Wydział Kultury LVI-958, Serie międzynarodowe (wydania w Polsce), k. nlb.

39 Matierialy sowieszczanija priedstawitielej knigoizdatielnych centrow i enciklopediczeskich izdatelstw socjalisticzeskich stran, Moskwa 1979, s. 32-42. 
talnie z bratysławskim „Tatranem”. Dzięki temu ukazało się na polskim rynku kilkadziesiąt albumów poświęconych wybitnym artystom i dziełom sztuki $^{40}$.

Z inicjatywy ZSRR w końcu lat 80 . ukazywały się cztery serie multilateralne (z udziałem oficyn ZSRR, Węgier, Czechosłowacji i NRD): „Technika obliczeniowa w budownictwie”, „Trwałość konstrukcji budowlanych”, „Ekologia w budownictwie” z udziałem wydawnictw z ZSRR, NRD, Polski, Bułgarii, Czechosłowacji i Kuby oraz „Oszczędność paliwa i energii elektrycznej" ${ }^{41}$.

Lektura cytowanych dokumentów świadczy, że wiele projektowanych serii nie zostało zrealizowanych, choć wielokrotnie toczyły się na ten temat dyskusje. Na ile był to efekt nieefektywności kooperacji, a na ile celowej obstrukcji ze strony uczestników tych spotkan - trudno powiedzieć.

Jako podsumowanie efektów narad można potraktować cytowane już wcześniej „Sprawozdanie o wykonaniu zleceń narady kierownictw ruchu wydawniczego krajów socjalistycznych w Berlinie", przygotowane przez stronę polską na kolejne spotkanie, które odbyło się w Warszawie. Dokument został sporządzony w listopadzie 1988 r. w oparciu o odpowiedzi udzielone w ankiecie skierowanej do delegacji narodowych, którą wypełniło pięć z nich (czechosłowacka, polska, węgierska, wschodnioniemiecka i sowiecka).

Za ewidentne niepowodzenie uznano w nim współpracę w ramach Rady Koordynacyjnej. Co prawda ,jest faktem, że Rada Koordynacyjna zwróciła uwagę na potrzeby upowszechniania naszych książek w krajach niesocjalistycznych. Należy jednak przemyśleć inne formy współpracy w tym względzie. Albo - jak proponuje Polska - przekształcić Radę Koordynacyjną w Radę Konsultacyjną, albo - zgodnie z propozycją ZSRR oraz CSRS ożywić działalność, którą miała się zajmować Rada, na poziomie wyspecjalizowanych w pracy zagranicznej agencji lub instytucji naszych krajów, albo wręcz - co zgłasza W[ęgierska]R[epublika]L[udowa] - pozostawić działalność tego rodzaju poszczególnym krajom" (jak wzmiankowałem wcześniej w zaleceniach narady warszawskiej znalazł się postulat likwidacji wskazywanego gremium).

W sprawozdaniach delegacji na posiedzenie skrupulatnie wyliczono liczbę tytułów i egzemplarzy przekładów literatury pięknej wraz z literaturą dla dzieci i młodzieży z krajów socjalistycznych w latach 1986-1987 (w przypadku Polski liczby te zawiera tabela 1).

\footnotetext{
40 AAN, KC PZPR, Wydział Kultury, LVI-1537, Sprawozdanie o wykonaniu zleceń...

${ }^{41}$ Zob. jak wyżej.
} 
Tabela 1. Przekłady książek literackich z państw bloku wschodniego wydane w Polsce w latach 1986-1987²

\begin{tabular}{|l|r|r|r|r|}
\hline \multirow{2}{*}{ Kraj } & \multicolumn{2}{|c|}{1986} & \multicolumn{2}{c|}{1987} \\
\cline { 2 - 5 } & Tytuły & $\begin{array}{c}\text { Nakłady } \\
\text { w tys. egz. }\end{array}$ & Tytuły & $\begin{array}{c}\text { Nakłady } \\
\text { w tys. egz. }\end{array}$ \\
\hline Bułgaria & 8 & 264,3 & 4 & 122,6 \\
\hline Czechosłowacja & 21 & 564,6 & 15 & 615,4 \\
\hline Jugosławia & 11 & 525,4 & 8 & 161,5 \\
\hline Kuba & 1 & 10,3 & 2 & 35,7 \\
\hline NRD & 10 & 337,1 & 13 & 627,8 \\
\hline Rumunia & 2 & 30,6 & 2 & 22,5 \\
\hline Węgry & 6 & 281,6 & 11 & 627,6 \\
\hline ZSRR & 88 & 6206,3 & 99 & 4761,9 \\
\hline Razem & 147 & 8220,2 & 154 & 6975,0 \\
\hline
\end{tabular}

W cytowanym dokumencie zwracano uwagę na nowe warunki ekonomiczne, w jakich przychodziło działać wydawnictwom. Dotychczasowa monopolistyczna pozycja wielu z nich została zakwestionowana. Usługi wydawnicze i poligraficzne stawały się elementem komercyjnego handlu. Próba wejścia $\mathrm{z}$ książką wschodnioeuropejską na rynki zachodnie napotykała na ogromne trudności ze względu na zbyt długi proces produkcyjny i małą operatywność przedsiębiorstw zajmujących się handlem zagranicznym. Już wówczas strona polska formułowała pogląd, że trudności, na jakie natrafiały wydawnictwa państw bloku wschodniego wynikały z różnych mechanizmów ekonomicznych, które dotyczyły książki. W Polsce wydawnictwami rządziły reguły reformy gospodarczej, stawały się one przedsiębiorstwami samodzielnymi i samofinansującymi się. „Nie uwzględnia się jak dotąd książki jako towaru specjalnego”. Książka - konkludowano - podlega zbyt wielu obciążeniom fiskalnym.

Trudności we współpracy krajów socjalistycznych wynikały ponadto z różnego zaawansowania technologicznego: technika komputerowa była najdalej posunięta $\mathrm{w}$ wydawnictwach w NRD, które wykorzystywały ją w całym procesie produkcyjnym książek oraz dla analiz ekonomicznych, handlowych itp. W CSRS około połowa wydawców korzystała wówczas z komputerów. Dużo gorzej pod tym względem sytuacja przedstawiała się w pozostałych krajach poddanych analizie, choć w Polsce na bazie komputerowej powstawała Wielka encyklopedia powszechna $\mathrm{PWN}^{43}$.

\footnotetext{
42 Zob. jak wyżej.

43 Zob. jak wyżej.
} 
W przyjętych 2 grudnia 1988 r. zaleceniach narady warszawskiej zapowiedziano zorganizowanie kolejnego takiego spotkania w Czechosłowacji w 1990 r. Miało być ono poświęcone działalności wydawniczej i jej materialno-technicznej bazie w warunkach przemian zachodzących w krajach socjalistycznych. Nie udało się ustalić, czy to posiedzenie doszło do skutku. Bez względu na rozstrzygnięcie tej kwestii od 1989 r. blok wschodni ulegał coraz poważniejszemu demontażowi. W nowych warunkach ekonomicznych współpraca wydawnictw Europy Wschodniej odbywała się na nowych, rynkowych zasadach.

\section{Konkluzje}

1. Narady kierownictw ruchu wydawniczego, wydawców i księgarzy państw bloku wschodniego były organizowane od połowy lat sześćdziesiątych do lat osiemdziesiątych XX w. Stanowiły element koordynacji pracy wydawnictw pod kątem ideowo-politycznym.

2. Owe cele polityczne i ideologiczne były wyznaczane przez kierownictwa partyjne państw - uczestników tych spotkań, a w istocie rzeczy przez decydentów moskiewskich. To z tego szczebla docierały wytyczne, które w trakcie posiedzeń przebierały postać zaleceń. Dotyczyły one m.in. wydawania dzieł związanych z rocznicami wydarzeń i postaci ważnych z punktu widzenia ideologii i ruchu komunistycznego oraz interpretujących z tej perspektywy problemy świata współczesnego. Ta kooperacja przybierała najczęściej postać tłumaczeń wybranych książek na języki narodowe krajów socjalistycznych. Ukazywały się one w seriach wydawniczych (najbardziej znane: „Socjalizm - Doświadczenia, Problemy, Perspektywy”, „Realny Socjalizm”, „Biblioteka Zwycięstwa”).

3. Uczestnicy narad próbowali opracować mechanizm wyjścia z ofertą wydawniczą poza „żelazną kurtynę”. W tym celu utworzona została Rada Koordynacyjna Krajów Socjalistycznych dla Wydawnictw Literatury Społecznej, Socjalistycznej i jej Rozpowszechniania w Krajach Niesocjalistycznych. Efekty jej działalności były jednak niewielkie i budziły coraz większe zastrzeżenia członków tego gremium.

4. Na obecnym etapie badań trudno udzielić precyzyjnych odpowiedzi na wiele kwestii dotyczących wewnętrznego funkcjonowania mechanizmu narad. W co najmniej trzech przypadkach na jej forum doszło do napięć o charakterze politycznym (stanowisko delegacji czechosłowackiej w 1968 r. i rumuńskiej w 1969 i 1971 r.).

5. Efektywność współpracy projektowanej w trakcie spotkań była daleko mniejsza niż ta zapisana w uchwalanych dokumentach. Niektóre planowane serie wydawnicze nie zostały zrealizowane, inne owocowały tylko 
nielicznymi publikacjami. Odnosi się wrażenie, że mechanizmy współpracy były nieskuteczne, a zainteresowanie kooperacją - umiarkowane. Kwestią nierozstrzygniętą musi na razie pozostać odpowiedź na pytanie, na ile był to efekt świadomego działania przynajmniej niektórych uczestników tych działań.

\section{Streszczenie}

Autor artykułu na podstawie materiałów archiwalnych i prasowych analizuje dokumenty obrazujące przebieg i efekty narad kierownictw ruchu wydawniczego, wydawnictw i księgarstwa państw bloku wschodniego z lat 1965-1988. Twierdzi, że ta forma współpracy realizowała cele ideologiczne i polityczne narzucone przez Moskwę i kierownictwa partyjne partii komunistycznych Europy Środkowo-Wschodniej. Dotyczyły one m.in. wydawania dzieł związanych z rocznicami wydarzeń i postaciami ważnymi z punktu widzenia ideologii i ruchu komunistycznego oraz interpretujących z tej perspektywy problemy świata współczesnego. Ta kooperacja przybierała najczęściej postać tłumaczeń wybranych książek na języki narodowe krajów socjalistycznych. Ukazywały się one w seriach wydawniczych (najbardziej znane: „Socjalizm - Doświadczenia, Problemy, Perspektywy”, „Realny Socjalizm”, „Biblioteka Zwycięstwa”). Uczestnicy narad próbowali (z mizernym efektem) wyjść z ofertą wydawniczą poza ,żelazną kurtynę”. W tym celu utworzona została Rada Koordynacyjna Krajów Socjalistycznych dla Wydawnictw Literatury Społecznej, Socjalistycznej i jej Rozpowszechniania w Krajach Niesocjalistycznych. Efekty jej działalności były jednak niewielkie i budziły coraz większe zastrzeżenia członków tego gremium. Efektywność narzuconej współpracy, której formę stanowiły narady, była daleko mniejsza od planowanej.

Słowa kluczowe: „książka socjalistyczna” - ruch wydawniczy w bloku wschodnim: mechanizmy kontroli i ideologizacji - komunizm w Europie Wschodniej - narady wydawców i księgarzy państw bloku wschodniego zimna wojna a książka. 
Summary

\section{How the „socialist book" was created? The meetings of publishers and booksellers from Eastern Bloc countries 1965-1988}

On the basis of the press and archival materials author of the article provides an analysis of documents presenting the course and effects of the meetings of the book publishing and book trade managing boards from Eastern Bloc countries in the years 1965-1988. Dariusz Jarosz maintains that this form of co-operation implemented ideological and political aims imposed by Moscow and leadership of communist parties from Middle Eastern Europe. These aims dealt with - among others - publishing books connected with anniversaries of historical events and with persons who were important from the communist movement ideology point of view and which interpreted modern world's problems from this perspective. This co-operation was mostly realised through translation of selected books into national languages of the socialist countries. These books were published in series (the most known were Socialism - Experiences, Problems, Perspectives (,Socjalizm - Doświadczenia, Problemy, Perspektywy”), The Real Socialism („Realny Socjalizm”), The Library of Victory („Biblioteka Zwycięstwa”)). The participants of the meetings tried (with mediocre effect) to bring their offer beyond the Iron Curtain. In order to do so there were established special The Socialist Countries' Coordination Board for Publishing and Dissemination of Social and Socialist Literature in Non-Socialist Countries. The effects of the Board's activities were very limited and raised many doubts among the members of this body The effectivity of imposed co-operation, embodied by the discussed meetings was much smaller than planned.

Keywords: „socialist book”- publishing in Eastern Bloc: the mechanisms of control and ideologization - communism in Eastern Europe - meetings of publishers and booksellers of Eastern Bloc countries - cold war and books. 